\title{
Internet governance as 'ideology in practice' - India's 'Free Basics' controversy
}

\section{Anita Gurumurthy}

IT for Change, India

\author{
Nandini Chami \\ IT for Change, India \\ Published on 30 Sep 2016 | DOI: 10.14763/2016.3.431
}

\begin{abstract}
The paper examines the recent Free Basics controversy in India, which triggered a national level policy debate on the appropriate regulatory response to differential pricing of data services, employing the theoretical framework of 'ideology in practice'. Unpacking 'openness' in design, 'inclusion' in provisioning and 'empowerment' in use as contested concepts in the policy process, the paper demonstrates a paradoxical conflation of oppositional interpretations of access. Tracing the material-discursive practices of actors in the debate and scrutinising everyday practices of the internet for their moral claims, the paper examines if and how hegemonic discourses of economic globalisation are challenged, and alternative meanings of the internet etched in contemporary political agenda on internet governance in India.
\end{abstract}

Keywords: Internet governance, Net neutrality, Facebook, Internet access

\section{Article information}

Received: 26 Apr 2016 Reviewed: 17 Jun 2016 Published: 30 Sep 2016

Licence: Creative Commons Attribution 3.0 Germany

Competing interests: The author has declared that no competing interests exist that have influenced the text.

URL:

http://policyreview.info/articles/analysis/internet-governance-ideology-practice-indias-free-basics-con troversy

Citation: Gurumurthy, A. \& Chami, N. (2016). Internet governance as 'ideology in practice' - India's 'Free Basics' controversy. Internet Policy Review, 5(3). https://doi.org/10.14763/2016.3.431

This paper is part of Doing internet governance, a special issue of Internet Policy Review guest-edited by Dmitry Epstein, Christian Katzenbach, and Francesca Musiani. 


\section{INTRODUCTION: UNDERSTANDING INTERNET GOVERNANCE AS 'IDEOLOGY IN PRACTICE'}

Policy formulation is not a value-neutral technical project based on "empirical measurements of inputs and outputs" (Fischer and Gottweis, 2015, p. 2). It is an interpretive exercise in which the "empirical" is itself framed by "normative analysis" (ibid). What this means is that public policy processes become the battlefield of an intense struggle between different ideologies, in which some hold a position of dominance. Consequently, there are two imperatives for understanding public policy. Firstly, dominant ideologies as they are renewed, recreated and defended must be "empirically critiqued" in particular contexts (Gramsci, 2012, as cited in Mager, 2014a; Fuchs, 2011, as cited in Mager, 2014a) and secondly, "oppositional interpretations" (Fraser, 1990) marked by multiple interests must be surfaced so that in addition to a critique of the dominant, a grasp of 'alternative ideologies in practice' is made possible.

The rapidly evolving sphere of internet governance is a significant site of public policy contestation nationally and internationally. Imaginaries of policy principles in the internet arena are polarised between "market-directed and profit-motivated [vs] social justice and wealth re-distribution" ideologies (Sarikakis, 2004). On one side of the debate are dominant actors making an impassioned plea for a freedom-from-state-control position, resorting to internet exceptionalism to further their argument (Chenou, 2014). Countering this marketdirected thinking are interventions such as the $\mathrm{P}_{2} \mathrm{P}_{1}$ movement advocating for the preservation of the internet as a global commons. This ideological "battle over the institutional ecology of the digital environment" (Benkler, 2006) does not play out identically on every single occasion. At times, the hegemonic power of market-directed ideologies is furthered; while at other times, it is destabilised.

A study of the ideological force field of internet policy is therefore about identifying how hegemonic ideas find material-discursive manifestations in specific political conjunctures, and the conditions under which they are destabilised. Tracing and framing moments of political decisions that structure public controversies becomes an especially useful strategy in this endeavour.

Using the Free Basics controversy in India as an exemplar, this paper explores the ongoing contestation for political legitimacy between market-directed and social justice-oriented imaginaries of access in internet policy debates. The controversy represents a significant milestone in policy discussions concerning the internet in India. In 2015-16, the Telecom Regulatory Authority of India (TRAI) initiated public consultations on net neutrality. This coincided with the launch and marketing of the Free Basics service by Facebook2, which elicited a highly polarised public sentiment. TRAI's call for a public discussion on differential pricing for data services snowballed into a widely debated controversy on Facebook's zero service, with over 2.4 million submissions.

In analysing the Free Basics controversy, the paper adopts an 'ideology in practice' framework that views ideology as a "set of shared beliefs, inscribed in institutions, bound up with actions, and hence anchored in reality" (Boltanski and Chiapello, cited in Mager 2014b, p. 773), rather than a "moralizing discourse" (Mager, 2014b, p. 773). Narratives of access - in the Free Basics debate and others that emerged at around the same time as the controversy - are hence studied in relation to both material and discursive practices of the internet. The paper offers a critique of 
contemporary public policy articulation on internet governance in India, recovering from social practice the contested meanings of the internet and what this suggests for its design, provisioning and use.

\section{A BRIEF OVERVIEW OF THE FREE BASICS CONTROVERSY}

In January 2015, the Government of India's Department of Telecommunications constituted an expert committee to examine the advantages and limitations of net neutrality from a public policy perspective (GOI, 2015, p. 90). Soon after, in March 2015, TRAI released a paper on overthe-top (OTT) services for wider consultation. At around the same time, Facebook launched its Internet.org zero-rated services ${ }_{3}$ in India, in partnership with Reliance Communications, a leading Internet Service Provider (ISP). A month later, another telco, Bharti Airtel, announced its zero-rated service 'Airtel Zero'.

Reacting to these threats to net neutrality, a loose coalition of tech-entrepreneurs, internetfreedom activists and free/libre open source software (FOSS) aficionados launched a nationwide campaign - Save the Internet - which became a roaring success. By April 2015, when the consultation process closed, users had sent over one million emails in support of net neutrality to TRAI. To tackle the increasing hostility to its zero service platform, Facebook embarked on a massive counter-offensive arguing that net neutrality considerations should not lead to a clampdown on solutions for expanding connectivity to the most marginalised (Zuckerberg, 2015).

A couple of months later, in July 2015, the expert committee on net neutrality submitted its final report to the Government of India, recommending that content and application providers be prevented from sidestepping the core principle of net neutrality, even if this was ostensibly serving public purposes (GOI, 2015). Facebook made its next move, even when a decision on net neutrality regulation was still pending. In September 2015, Facebook relaunched the Internet.org service as Free Basics, accompanied by a number of assertions about the nonexclusivity and openness of this new avatar. These claims were summarily dismissed by members of the Save the Internet campaign (Murthy, 2016).

In December 2015, in the middle of this fervid exchange, TRAI issued a second consultation paper on differential pricing and zero-rated services, along with a directive to Reliance Communications to temporarily suspend Free Basics. An extensive public debate followed, with proponents and opponents of zero-rated services marshaling their forces (TRAI, 2016a). Proponents argued the need for pricing innovations as a creative solution to the access divide, whilst opponents reiterated concerns about emergence of a lesser internet for users with limited ability to pay.

In the proponent camp, the main voices were that of Facebook, key telecommunication service providers and their professional associations. The face of the opponent camp in the public discourse was the Save the Internet campaign, but a number of civil society organisations, free software activists and tech start-ups also joined in.

At the close of the consultative process, in February 2016, TRAI (2016a) issued an outright ban on all forms of differential pricing in data services (including zero-rated services), with exemptions only for public emergency services and closed electronic networks (intranets). 


\section{3. 'IDEOLOGY IN PRACTICE' AS METHODOLOGICAL FRAMEWORK}

As mentioned earlier, an 'ideology in practice' frame is used to interpret the Free Basics debate. In this approach, ideology is seen as 'lived relations', the totality of discursive and material practices and not merely the disembodied representation of reality (Eagleton, 1991; Mager, 2014a). The project of hegemony thus becomes a perpetual work-in-progress: both discourse and social practice become the vehicles through which dominant ideologies are sometimes furthered, and at other times destabilised (Mager, 2014a).

The paper adopts a Critical Discourse Analysis (CDA) of the key ideologies of 'access' at work in the TRAI policy consultation. As CDA recognises discourse as social practice and not just as text (Fairclough and Wodak, 1997), the following two strategies have been adopted to recover the varying imaginaries of access characterising the semantics of the debate. First, select submissions received by TRAI as part of this debate have been assessed, through an open coding process that identified "contested concepts" 4 reflecting the key points of contestation and tension. As time and resource limitations rendered a detailed examination of all 2.4 million responses received by TRAI implausible, submissions to the call for 'counter-comments' issued by TRAI during the second stage of the public consultation process 5 have been selected for analysis. The format of counter-comments (similar to the 'rebuttals' in classic debate formats) lends itself well to tease out the multiple and intertwining ideological threads characterising a debate. In each 'counter-comment' submission, the petitioner (whether proponent/opponent of differential pricing in data services) intensively engages with the issues/concerns flagged by the other side and offers a concluding argument for TRAI's consideration.

Next, the technological means or practices adopted by the key actors in the public domain have also been analysed. The focus here is on techno-mediated campaigns, digital polls, etc., used by key actors to consolidate or defend their respective ideological positions in the Free Basics debate. This is critical not only because "ideologies have a material existence and are not confined to the ideational realm" (Fuchs, 2007), but also because of the unique nature of the internet as a media artifact whose material substrata is extremely malleable and "manipulable" (Winokur, 2008). The control and re-shaping of this substrata is vital to the production of internet access ideology (ibid).

TRAI's ruling is then examined for its ideological import; its position vis-à-vis dominant market-directed ideologies of access. The ruling is further juxtaposed with access imaginaries located in technological practices peripheral to or undefined in mainstream public discourse. For this, we examine the Chennairains.org portal set up by members of the free software community during the flash floods in the city of Chennai, and the Shame the Rapist campaign launched by activists to challenge and subvert the mainstream narratives about rape. These cases are used to highlight how alternative norms of access evident in social practices may tend to be eclipsed in policy debates. 


\section{THE MATERIAL-DISCURSIVE PRACTICES IN THE FREE BASICS CONTROVERSY}

\subsection{DISCURSIVE THREADS IN THE DEBATE}

A detailed reading of the counter-comments received during the public consultation by TRAI demonstrates that in the Free Basics controversy, multiple ideologies of access are enacted through the contested concepts of 'openness' in design, 'inclusion' in provisioning and 'empowerment' in use, as indicated in Table 1 . Of the 23 discrete counter-comments6, 16 oppose $_{7}$ all forms of differential pricing (including zero-rated services) while seven are in support.8

Ideological hues of a debate are usually not polarised in strict binaries. For the purposes of this analysis, while the two opposing ideologies of access discussed earlier - market-directed and social justice (Sarikakis, 2004) - are used to identify and label the dominant and alternative at the first level (see Table 1), it is also recognised that proponents and opponents of Free Basics are not divided neatly on these lines.

Table 1: Ideologies of access at work in the Free Basics controversy

\begin{tabular}{|c|l|l|}
\hline $\begin{array}{c}\text { Contested } \\
\text { concept }\end{array}$ & $\begin{array}{c}\text { Dominant ideologies of } \\
\text { access (market-directed } \\
\text { imaginaries) }\end{array}$ & $\begin{array}{c}\text { Alternative ideologies of } \\
\text { access (redistribution and } \\
\text { social justice-oriented } \\
\text { imaginaries) }\end{array}$ \\
\hline Open design & $\begin{array}{l}\text { - Openness in internet design is } \\
\text { about ensuring that consumer } \\
\text { autonomy is not constrained. }\end{array}$ & $\begin{array}{l}\text { - Openness in internet design is } \\
\text { about ensuring unrestrained } \\
\text { access to the full internet for all. } \\
\text { - Zero-rated services may be } \\
\text { allowed under circumstances } \\
\text { where they do not result in unjust } \\
\text { discrimination }\end{array}$ \\
\hline Inclusive & $\begin{array}{l}\text { - Inclusive access is about } \\
\text { ensuring affordable access to } \\
\text { marginalised groups through } \\
\text { expansion of telecom market } \\
\text { coverage. }\end{array}$ & $\begin{array}{l}\text { - Inclusive access is about } \\
\text { ensuring universal access to the } \\
\text { full internet, including through } \\
\text { public provisioning. } \\
\text { - Inclusive access is about } \\
\text { recognising the internet as a public } \\
\text { good. }\end{array}$ \\
\hline Empowering & $\begin{array}{l}\text { use } \\
\text { and capabilities of individual users } \\
\text { through access to the benefits of } \\
\text { connectivity. }\end{array}$ & $\begin{array}{l}\text { The internet is a critical enabler } \\
\text { of rights. } \\
\text { - The internet is "a portal of } \\
\text { possibilities" for individuals facing } \\
\text { disadvantages of poverty, minority } \\
\text { gender identity, and disability. }\end{array}$ \\
\hline
\end{tabular}

The policy goal of 'access for all' at a meta level is seen as possible through different routes that strategically juxtapose different normative ideals in the rhetoric of design, provisioning and use. Rhetorical devices employed to construct policy narratives (pro or against Free Basics) therefore need to be studied carefully for their normative import. Actors may align on either side of the debate, even while their normative vision about the internet and internet governance is at variance. The various discursive tactics employed by the key actors in the wider public sphere are interlaced in the analysis: 
a. The contestation over the normative ideal of open design is broadly between the notion of openness as consumer choice and as unrestricted access to the full internet. The majority of proponents profess a market-directed idea of openness that emphasises the creation of an internet architecture in which "every consumer (has) the option of choosing the full internet" (Yoo, 2016, p. 4)Facebook and key TSP associations also went on to make statements inside and outside of the consultative process about how this stance was keeping in line with their commitment to the principle of net neutrality (Facebook, 2016; ISPAI, 2016; NDTV, 2015). The Cellular Operators Association of India even launched a campaign titled \#SabkaInternet (internet for all) in May 2015 to drive this point home.

In contrast, all 16 opponents understand the open internet as signifying "the full internet in its infinite possibilities" (Sharma, 2016, p. 2)From this point of view, differential pricing is objectionable as it paves the way for telecom service providers to "pick winners in websites and app members, taking this power away from consumers" and consolidates the power of online oligopolies (Save the Internet, 2016, p. 2). In fact Save the Internet built an entire campaign that acquired a support base of over one million people, keeping the spotlight on this argumentation. They partnered with a homegrown stand-up comedy group All India Bakchod to parody how a SabkaInternet (internet for all) had been reduced to MereBaapkaInternet (an internet that is my father's fiefdom by the TSPs.

b. Two opposing normative ideals of inclusive access are at work in the Free Basics debate. The dominant imaginary is that inclusive access is about expanding the benefits of connectivity to consumers at the bottom of the pyramid through innovative market mechanisms that ensure affordable access. The emphasis here is on stressing the viability/feasibility of differential pricing as a solution to the problem of inclusive access. Yoo uses Facebook and third-party research on Free Basics to demonstrate that the service does not lock-in users into a walled garden (Yoo, 2016). Similarly, Facebook's submission argues that "Our data, from over 35 countries...(reveals that) Free Basics has...helped in bringing people online faster and incentivized them to access the broader internet" (Facebook, 2016, p. 12).

With the debate heating up in December 2015, Facebook decided to launch a blitzkrieg ad campaign (Newsminute, 2015) using billboards, television ad-spots and full-page newspaper

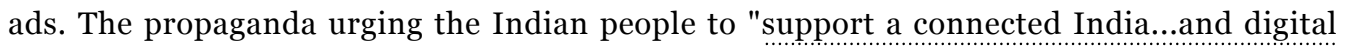
equality" (read, inclusive access) through Free Basics (Newsminute, 2016), purportedly cost Facebook US 44 million dollars (Backchannel, 2016).

The counter-view to the rhetoric of market-led affordable access is that of 'universal access for all', even for those without the ability to pay, through mandatory public provisioning. This standpoint is articulated by 11 opponents. In fact, two among them - civil society coalitions Access Now and others and Knowledge Commons and others - explicitly state that internet infrastructure must be treated as a commons. Interestingly, the leading voice on the side of the opponents - Save the Internet - subscribes to the dominant imaginary. Their only point of difference with the proponents (of Free Basics) is in their assertion of the need to respect the inviolability of the net neutrality principle in designing connectivity solutions (Save the Internet, 2016).

c. The ubiquitous narrative of empowerment is widely invoked. One proponent and four opponents root for an expansion of individual choice, while eight opponents espouse a human rights frame that views the internet as an enabler of rights. As feminist scholarship in the global South cautions, the individualist narrative of empowerment is easily susceptible to co-option by neoliberal economic forces (Sharma, 2008). In this contestation as well, empowerment is 
strategically deployed by Facebook, which argues that zero-rated services such as Free Basics expose new users to "the potential of the internet and how to use this potential to better their lives" (Facebook, 2016, p. 4).

In April 2015, Facebook used a direct blog appeal from Mark Zuckerberg to build support for its ideological position that "...arguments about net neutrality shouldn't be used to prevent the most disadvantaged people in society from (new) opportunit(ies)" (Zuckerberg, 2015). Through its ad campaign in December 2015 for a "Connected India", Facebook invoked the narrative of 'empowerment as choice' in a more explicit way. In these front cover, double page ads, stories of ordinary people empowered through Free Basics were aggressively peddled. In one story, Ganesh, a farmer from Maharashatra who had (ostensibly) doubled his yield after learning new cropping techniques from Free Basics became the compelling meme; Free Basics was a great leveler and objections of net neutrality activists came from an elite fringe. The rhetoric of rights is used also by Sony Pictures to argue against zero-rated services, which they claim pose a risk to the right to privacy (Sony Pictures, 2016).

On a separate note, 11 out of the 12 opponents in the debate articulate a universalist (even if inclusive) vision of internet-enabled empowerment. The only exception is the Internet Democracy Project (2016) whose submission stresses the internet's propensity as "a portal of possibilities" especially for individuals facing particular disadvantages of poverty, minority gender identity or disability.

Unsurprisingly, these differences in the ideological positions on access lead to different constructions of the idea of 'public interest' in access policy by the various actors involved. Actors (both proponents and opponents) who espouse a market-centric imaginary of design, provisioning and use tend to believe that public interest in this debate is about ensuring that there is no distortion of the internet as a level playing field for perfect competition, whether through monopolistic business practices or interventionist regulation. For example, the starting point of the template email created by Save the Internet campaign in April 2015 to enable interested individuals to send in their response to TRAI's consultation on OTT services was that "No new regulatory framework in the telecom sector is required for internet services and apps - and no such regulation should come into effect in future either".

For actors invested in an alternative ideal of access, mostly opponents, public interest is about ensuring, pro-actively, an inclusive internet architecture that enables the full participation of marginalised groups.

\subsection{HOW KEY ACTORS IN THE FREE BASICS DEBATE DEPLOYED TECHNOLOGY IN THE BATTLE OF IDEOLOGIES}

In the keenly contested battle to claim ideological supremacy, Facebook and the ISPs on the proponent side, and Save the Internet on the opponent side used not just discursive practices but also specific technological means and actions.

The Cellular Operators Association of India (COAI) bombarded mobile phone subscribers with SMSes reading "COAI supports \#SabkaInternet.9 I believe that I should have the right to choose what I want to access on the Internet. To support, give a missed call". Through this effort, COAI claimed to have acquired four million supporters in one week (NDTV, 2015).

In December 2015, using its own social networking platform, Facebook sent notifications to its users urging them to send a message to TRAI to "save Free Basics...for digital equality in India". Users just had to 'click' on Facebook's template with the subject line "I support Free 
Basics in India" to send their message. 1.35 million messages were auto-forwarded to TRAI. Amidst allegations about doctoring these mass responses, Facebook was also pulled up by TRAI for "reducing a meaningful consultative exercise designed to produce informed decisions in a transparent manner into a crudely majoritarian and orchestrated poll” (TRAI, 2016c).

The Save the Internet campaign also built a similar online platform 10 . However, unlike Facebook's template, it permitted individuals to make a personalised appeal against zero-rated services to TRAI.

These instances reveal the sweet spot that platform control constitutes in the struggle for hegemony in the network society. As dominant actors vie for control, they mediate user experience by redefining the materialities of the multi-layered internet environment.

\section{TRAI'S RULING: OPENNESS, INCLUSION AND EMPOWERMENT}

\subsection{RULING ON DIFFERENTIAL PRICING}

On 8 February 2016, TRAI gave its ruling, banning all forms of differential pricing, including any kind of zero-rated services. With this, India became one among just two or three countries in the world to have taken such a policy position on differential pricing. Both the USA and the EU have soft-pedaled the issue of differential pricing, choosing to go in for a case-by-case evaluation of whether a zero-rated service arrangement violates net neutrality. TRAI's ruling thus goes against the grain of status quo ideology in global net neutrality regulation. However, this development arguing the need "to preserve the unique architecture of the internet as a global communication network" (TRAI, 2016b, para. 15) cannot automatically be assumed to have included discourses and ideologies peripheral to the mainstream debate on access. To explore whether it has, TRAI's argumentation justifying its ruling needs to be examined for its discourses on design, provisioning and use of the internet.

The starting point of the TRAI ruling is a belief in the dominant discourse of open design - the idea that openness is about ensuring complete freedom of choice for users. TRAI however uses this very narrative deployed by proponents of zero-rated services to arrive at the opposite conclusion. In TRAI's view, zero-rated services would constrain authentic freedom of choice, and should not be allowed owing to special traits of the internet marketplace:

a. information asymmetry between service providers and users which "leaves users with inadequate information to make an informed choice" (TRAI 2016b, para. 21), which cannot be solved by merely introducing "disclosure/transparency" requirements, as the internet is "an 'experience good' which can be understood properly only after being used"(ibid).

b. fluidity of the internet stemming from the fact that the very same user is a consumer of content at one moment, and a producer of content at another.

The connection between this idea of open design and access arrangements that TRAI draws is that telecommunication service providers should not be allowed to become gatekeepers of user experience, in the name of ensuring affordable access (TRAI, 2016b). While TRAI's ruling implicitly recognises 'connectivity for all' and 'affordability' as crucial policy agenda, it stops short of articulating (explicitly or implicitly) the necessary link between universal access to the full internet and the role of subsidised or free public provisioning to include those without the ability to pay. This, despite the fact that TRAI notes in its summation of the public consultation recommendations by some opponents of Free Basics that instruments such as Universal Data 
Allowance and Universal Service Obligation Fund can be 'alternative models' of "providing free internet access" (TRAI, 2016b, para. 11).

Although TRAI's consultation did seek answers to the question of free internet access, its final ruling was conspicuously silent on provisioning approaches to address 'connectivity for all'. In fact, TRAI's discussion on exemptions in view of the need to bring more users on the internet" (TRAI, 2016b, para. 32) shows its preference for market mechanisms (e.g. tariff differentiation independent of content, like promotional offers of limited free data) and completely circumvents concerns such as citizen access to e-governance services, necessary not only from an inclusion standpoint, but also a citizen participation and empowerment vantage, for instance. In other instances as well, such as for an effective last-mile broadband network, TRAI has recommended a market-based approach that uses suitable commercial models which attract private investment.

Conspicuously, in May 2016, TRAI issued a new consultation paper on 'free data', inviting the public to deliberate upon ISP-agnostic platforms that provide free data to users, through a 'do not charge' or discount-based model (TRAI, 2016d). Shifting away from its position of a total prohibition of zero-rated services by ISPs to one that is more explicitly aligned with the dominant ideology of internet exceptionalism, TRAI endorsed the view that internet companies must be allowed to offer zero-rated services as long as telcos are not involved (Singh, 2016).

TRAI's ruling banning all forms of differential pricing reveals an unequivocality about 'openness' and its relationship with authentic user choice. Yet, its invocation of the special traits of the internet used against zero-rated services provisioning by ISPs, is the very logic that TRAI uses to argue in favour of free data offered by platforms, in its May 2016 position paper. These contrasting positions, while consistent with the idea of the internet 'marketplace', reflect policy ambivalences not confined to internet access alone, but in general, about the multiplicity of public interest agendas that implicate internet design, provisioning and use.

\subsection{PRACTICES AT THE PERIPHERIES: WHAT THEY IMPLY FOR POLICY}

The internet is multivalent; it means different things to different users. Bloggers trading in the currency of hyperlinks and social media users attuned to the streaming culture of apps belong to two different online universes (Derakhshan, 2015). Similarly, users on high-end data plans and those on lower-end plans have very different experiences of the internet - as the differences in 'waiting periods' (Cheng, 2011) stemming from different connection speeds produce different temporalities.

These diverse socialities of the internet generate imaginaries of design, provisioning and use that can be valuable for policy. But their underlying implications for specific technological policy choices may not garner the visibility to compete with the dominant meanings. Two relatively low key instantiations of internet use coterminous with the high profile Free Basics public debate are discussed below. TRAI's ruling on differential pricing is examined in relation to both.

\section{The case of Chennairains.org}

In December 2015, at around the same time the Free Basics controversy was in its final throes, the southern Indian city of Chennai was hit by flash floods. The disaster response systems of public authorities and the local government were overwhelmed, and citizen volunteers started spontaneously plugging into relief and aid coordination efforts. Members of the free software community played a critical role in this process: setting up a Github portal to map inundated areas and a website (chennairains.org) to coordinate rescue and aid, through a range of crowdsourcing innovations. They also set up an open database consolidating calls for help and 
offers of assistance received from different neighbourhoods. Two hundred volunteers designed and led this initiative whose reach spanned the entire city, without government/institutional backing.

The appropriation of the internet to coordinate emergency relief in Chennai highlights design aspects of the internet that make possible the creation of decentralised information networks based on locally-driven data structures. It brings to sharp focus not just the "manipulability" of the internet's material substrata (Winokur, 2008), but the imperative for an access policy that can respond to both individual and collective wellbeing, making the benefits of the internet accessible unconditionally, at all times, to all. However, it is noteworthy that in this case, it was a privileged 'few' with access, who acted in the interests of the marginalised 'many'. While this elite group did orchestrate a moment in which inclusion into the gains of the internet was democratised, this social network and its specific materiality does call to question key erasures in the TRAI ruling. These include respectively, the imaginary of a 'right' to access, that is, the de facto possibility for all citizens to leverage the internet as a public good; and a legal regime on data - in which data processes can be designed, governed and managed in a decentralised manner as per stated norms (on anonymity, privacy, community wellbeing/public good, etc.).

\section{The case of Shame the Rapist}

'Shame the Rapist', a campaign initiated by feminist activist Sunitha Krishnan in February 2015, used the internet as a site of protest to obtain justice for rape victims. Rape-videos circulating on the internet were identified by Sunitha and her team, and after blurring out the faces and the bodies of the victims and highlighting those of the perpetrators, they were uploaded to YouTube - with an express call requesting members of the public to come up and identify the men in the videos so that justice could be delivered. The attempt here was to use the very same strategy used by perpetrators to silence their victims, and turn the mainstream discourse of 'the shame of rape' on its head. Following this, Sunitha moved the Supreme Court, as the police did not make any arrests (First Post, 2015; Nair, 2015). What this campaign demonstrated was that in the open internet, women are open game; and yet, particular grammars of participation in the open spaces of the internet can also potentially subvert gender power.

TRAI's ruling on differential pricing explicitly affirms the "right to express oneself as well as the right to receive information" as "critical elements in the use of the internet" (TRAI, 2016b, para. 24). It establishes norms of internet design that can advance "the free speech rights of the citizens, by ensuring plurality and diversity of views, opinions and ideas". Implicitly, therefore, TRAI invokes the imaginary of 'the full internet as a precursor for empowering use'.

While this assertion per se may be true, what 'Shame the Rapist' tells us is that openness is not necessarily empowering. The politics of embodiment mediate the 'experience good' that the internet is; negotiating openness online (and the default misogyny one encounters) calls for particular use skills, stemming as it does in the case of this campaign, from radical interpretations of the internet.

Multiple and oppositional interpretations of the internet bring different norms at loggerheads, complicating governance considerations. As 'Shame the Internet' demonstrates, framings of an 'open-internet-for-empowering-use' may eclipse access imaginaries delegitimised in public discourse, unless design considerations in policy account for the "participatory parity" (Fraser, 1990) of women and marginal genders online. This is a particularly daunting task, as even a quick examination of the emerging policy debates around intermediary liability demonstrates.

On the one hand, legislation that sets limits on the openness of the internet through 
intermediary liability for the content that internet platforms carry may be essential to protect and promote the right to privacy, dignity and freedom from harm, especially of those who are vulnerable. On the other hand, the same legislation can end up making internet intermediaries take the side of powerful actors in public controversies, or censor unpopular opinions (especially those professed by minority groups) to avoid being penalised (Bose, 2015).

\section{CONCLUSIONS}

The internet is a key fault-line of contemporary global political economy - a political instrument of discursive and material interventions affirming, reinstating and shielding neo-liberal capitalism. In the internet economy, big corporations use expedient opportunism through ingenious discursive work to establish credence for their doings and misdoings. Content providers, for example, deploy the word 'platforms' in both their populist appeals to users and their marketing pitches, projecting themselves as "platforms of opportunity" (Gillespie, 2010).

In juridical and policy processes, these big players adopt different and even contradictory positions in different markets to suit their specific business interests. In the TRAI process, Facebook vociferously argued for a 'public interest' zero-rated service exemption to net neutrality regulation in India, but took a different position, in a similar contestation in the United States in 2014. As part of the group of 100 technology companies it signed a Silicon Valley petition to FCC arguing for an open internet in which there would be no form of discrimination in violation of the end-to-end principle (Guardian, 2014). The fact that India is an extremely important market for Facebook cannot be overemphasised with regard to its stance on zero-rated services. By 2017, India is expected to surpass the US to lead the global tally of the largest Facebook user base on the mobile (New Indian Express, 2016). On the other hand, Sony Pictures which batted for net neutrality as essential for safeguarding the right to privacy in the TRAI case, stayed out of the 2014 net neutrality contestation in the United States, refraining from signing the Silicon Valley letter. A Wikileaks scoop revealed that Sony did not want to "foreclose opportunities and deals" (Wikileaks, 2014) in the new rules on fast lane traffic that the FCC was contemplating.

Even within the same national jurisdiction, corporations revise their policy stances as market conditions shift in a rapidly evolving digital environment. Consider Google's back-and-forth within the policy debate on network neutrality in the United States (Svennson, 2009; Barr 2015).

As they become the curators of public discourse, the public roles that digital corporations play and the criteria by which they seek to be judged requires deep scrutiny. The discussion about Facebook and Free Basics in India shows an unethical use by Facebook of its own platform for political propaganda; a capture of the internet which is the primary terrain of the attention economy, to expand and reinstate its market power. After the regulator's ruling, Facebook board member Marc Andreessen's remark that India's decision to ban zero-rated services was "morally wrong" and revealed "anti-colonialist” baggage completely belied Facebook's original public commitments to provide deliverance to India's unconnected bottom of the pyramid. It spoke not just to the power of capitalism and class, but to racist prejudice.

Internet companies are neither natural allies of people's right to privacy, nor are they altruistic purveyors of the free and open internet. But market supremacy calls for sustained engagement in constructing "common sense". In the internet governance field, bodies like the Alliance for 
Affordable Internet (A4AI) and the World Bank have prescribed to developing countries strong dictums around market liberalisation and light touch regulation (A4AI, 2016; World Bank, 2016).

TRAI's ruling on net neutrality in February 2016, while establishing the moral validity of an open (as in full) internet, can also be read as a defense of neo-liberal market ideology that valorises individual rights to choice and free speech, one in which the norm of rights is deployed strategically to defend and stabilise the dominant ideology. The ruling on net neutrality in India, as it has been hailed, may be path breaking; but its normative boundaries suggest a common sense about the internet 'marketplace', where consumer-users must be able to make an informed choice, and Free Basics is antithetical to such choice. In this worldview, for the collectives that make up the marginalised many, the 'right to access the internet' still remains a moot point. Whether inclusion or empowerment will accrue from the norm of openness is left as an open question.

The semantics of the ruling do not afford any maneuvering space to imagine how a coherent and connected framework of design, provisioning and use can, or will, affirm a social justice view of policy. TRAI 's decision in May 2016 to initiate a fresh public consultation on designing new business models for providing free data to consumers without violating the prohibition on ISP gatekeeping further reduces the space for access imaginaries that are not market-centric. It is ironic that TRAI's latest position paper, suggesting that internet companies can offer zero-rated services in order to "give...consumers more choices for accessing the internet" (TRAI, 2016d, para. 9), ignores constraints monopoly platforms impose on "informed choice" (TRAI, 2016b, para. 15). It is impervious to the fact that digital platforms are "the new entrance doors of the digital society" (CNNum, 2014a) impacting "the unique architecture of the internet as a global communication network" (TRAI, 2016b, para. 15) that TRAI sought to protect so fervently in the Free Basics context from TSPs. In fact, the French Digital Council has astutely observed that platform neutrality is intrinsic to an open and sustainable digital environment (CNNum, 2014b).

Thus, public policy conjunctures become critical in either reinforcing hegemonic, exclusionary and exploitative ideologies of design, provisioning and use or in destabilising them. As the French Digital Council highlights, effective policy choices that ensure that "dominant players do not smother innovation" and promote "an environment that favour(s) alternatives" can unlock the internet's transformatory potential as " a vector for choice and creativity" (CNNum, 2014b, p. 40).

Meanings of the internet are being discovered and appropriated through the spontaneous actions of communities and individuals, and moral claims that challenge common sense arise continuously through these. The regulator's decision in India perhaps presents a new benchmark on net neutrality, marking a moment of destabilisation. But as noted, it signals the long road of continuing contestation for realising marginal imaginaries and legitimising an alternative discourse on access. The willing participation of users in furthering global digital capitalism (Mager, 2014a) complicates actions to give legitimacy and authority to alternative definitions of the internet. In a globalised world mediated by the internet, thinking about internet governance as a sub-national, decentralised, agenda-setting process may be the way to go, for a more democratic and diverse interpretation of community-specific mandates in policy. 


\section{REFERENCES}

A4AI. (2016). Policy and Regulatory Good Practices. Retrieved from http://1e8q3q16vyc81g8l3h3md6q5f5e.wpengine.netdna-cdn.com/wp-content/uploads/2016/o 4/A4AI-Policy-and-Regulatory-Good-Practices.pdf

Barr, A. (2015). Google and Net Neutrality: It is complicated. Wall Street Journal. Retrieved from http://blogs.wsj.com/digits/2015/02/04/google-and-net-neutrality-its-complicated/

Backchannel. (2016, Feb 2). How India pierced Facebook's Free Internet Program: The inside story of Mark Zuckerberg's attempt to gift data to a skeptical subcontinent.

https://backchannel.com/how-india-pierced-facebook-s-free-internet-

program-6ae3foffd1b4\#.1jfz3il84

Benkler, Y. (2006). The Wealth of Networks: How Social Production Transforms. Retrieved from

http://cyber.law.harvard.edu/wealth_of_networks/11._The_Battle_Over_the_Institutional_Ec ology_of_the_Digital_Environment

Bose, S. (2015). Australian law threatens to prevent us speaking out about injustice online. Retrieved from

http://www.abc.net.au/news/2015-11-06/bose-internet-gagging-and-free-speech/6915218

Cheng, C. (2011). Digital Temporalities: Temporal Plasticity in the Age of Internet. Retrieved from

https://www.google.co.in/url?sa=t\&rct=j\&q=\&esrc=s\&source=web\&cd=19\&ved=oahUKEwi44 KrryvXNAhWHM48KHYHGAK44ChAWCEowCA\&url=https\%3A\%2F\%2Fetd.lib.msu.edu\%2Fis landora\%2Fobject\%2Fetd\%253A1355\%2Fdatastream\%2FOBJ\%2Fdownload\%2FDIGITAL_TE MPORALITIES_--

_TEMPORAL_PLASTICITY_IN_THE_AGE_OF_INTERNET.pdf\&usg=AFQjCNGK4j1WqvVLusJGwrXhUEYG2Odrg\&sig2=XU7IYnySrZf5AFoPKh6d1Q

CNNum (2014a). Platform neutrality: Building an open and sustainable digital environment. Retrieved from

http://cnnumerique.fr/platform-neutrality-building-an-open-and-sustainable-digital-environm ent/

CNNum (2014b). Platform Neutrality:Building an Open and Sustainable Digital Environment. Retrieved from

http://www.cnnumerique.fr/wp-content/uploads/2014/o6/PlatformNeutrality_VA.pdf

Chenou, J.M. (2014). From Cyber-Libertarianism to Neo-liberalism: Internet Exceptionalism, Multistakeholderism and the Institutionalisation of Internet governance in the 1990 .

Globalizations Vol 11(2) pp 205-223. DOI: 10.1080/14747731.2014.887387

Eagleton, T. (1991). Ideology: An introduction. London:Verso

Facebook. (2016). Counter-comments to the TRAI Consultation on Differential Pricing. Retrieved from

http://www.trai.gov.in/WriteReadData/ConsultationPaper/Document/20160115040545507715 4Facebook.pdf 
Fairclough, N. L. and Wodak, R. (1997).Critical discourse analysis. In T. A. van Dijk (ed.), Discourse Studies: A Multidisciplinary Introduction, Vol. 2.Discourse as Social Interaction. (pp. 258-84). London: Sage.

Fischer, F. and Gottweis, H. (Eds.). (2012). The Argumentative Turn Revisited: Public Policy as Communicative Practice. Durham and London: Duke University Press.

First Post. (2015, April 13). Shame the Rapist Campaign: Activist Sunitha Krishnan gets 90 videos from rape survivors. First Post. Retrieved from

http://www.firstpost.com/living/shame-the-rapist-campaign-activist-sunitha-krishnan-receive s-90-videos-of-sexual-assault-2194697.html

Fraser, N. (1990). Rethinking the Public sphere: A Contribution to the Critique of Actually Existing Democracy. Social Text, No 25/2, pp 56-80. DOI:10.2307/466240

Gillespie, T. (2010). The politics of platforms. New Media and Society 12(3). 347-364. DOI:10.1177/1461444809342738

Government of India. (2015). Net Neutrality Report: DOT Committee. Retrieved from http://dot.gov.in/sites/default/files/u1o/Net_Neutrality_Committee_report\%20\%281\%29.pdf Internet Democracy Project. (2016) Counter-comments to the TRAI Consultation on Differential Pricing. Retrieved from

http://www.trai.gov.in/WriteReadData/ConsultationPaper/Document/20160115040915773347 4Internet_Democracy_Project.pdf

ISPAI. (2016, January 14). Counter-comments to the TRAI Consultation on Differential Pricing. Retrieved from

http://www.trai.gov.in/WriteReadData/ConsultationPaper/Document/20160115032803210911 oISPAI.pdf

Mager, A. (2014a). Defining Algorithmic Ideology: Using Ideology Critique to Scrutinize Corporate Search Engines. Communication, Capitalism and Critique, Vol 12 (1). Retrieved from http://www.triple-c.at/index.php/tripleC/article/view/439/641

Mager, A. (2014b).Algorithmic Ideology. Information, Communication and Society, Vol 5:5, 769-787. DOI: 10.1080/1369118X.2012.676056

Mark Zuckerberg. (2015, April 17). [Blog]. Retrieved from

https://www.facebook.com/zuck/posts/10102033678947881

McGee, R. and Edwards, D. (2016). Opening Governance: Change Continuity and Conceptual Ambiguity. IDS Bulletin Vol 47 (1). pp 1-22. Retrieved from http://opendocs.ids.ac.uk/opendocs/bitstream/handle/123456789/7686/IDSB_47_1_10.1908 81968-2016.103.pdf?sequence=1

Morozov, E. (2014). Don't believe the hype, the 'sharing economy' masks a failing economy. Guardian. Retrieved from

http://www.theguardian.com/commentisfree/2014/sep/28/sharing-economy-internet-hype-be nefits-overstated-evgeny-morozov

Murthy, M. (2015, December 26). Facebook is misleading Indians with its full page ads about 
Free Basics. The Wire. Retrieved from

http://thewire.in/2015/12/26/facebook-is-misleading-indians-with-its-full-page-ads-about-fre e-basics-17971/

Nair, H.V. (2015). 'What is the cyber cell doing?' Supreme Court horrified by rape video avalanche as victims turn to NGOs for help. Mail Online. Retrieved from http://www.dailymail.co.uk/indiahome/indianews/article-3036068/What-cyber-cell-doing-Su preme-Court-horrified-rape-video-avalanche-victims-turn-NGOs-help.html

NDTV. (2015, April 20). Telecom Operators Reaffirm Support for Net Neutrality. NDTV Gadgets 36o. Retrieved from

http://gadgets.ndtv.com/internet/news/telecom-operators-reaffirm-support-for-net-neutralitycoai-683373

New Indian Express. (2016, September 19). Facebook to have largest users from India by 2017: Study.

http://www.newindianexpress.com/nation/Facebook-to-Have-Largest-Users-from-India-by-20 17-Study/2015/o1/22/article2631687.ece

Newsminute. (2015, December 24). With full page ads, Facebook's blitzkreig ad campaign for Free Basics. The News Minute. Retrieved from

http://www.thenewsminute.com/article/full-page-ads-facebooks-blitzkrieg-ad-campaign-free-b asics-37050

Newsminute. (2016, January 12). Facebook is no charity and the 'free' in Free Basics comes at a price. The News Minute. Retrieved from

http://www.thenewsminute.com/article/facebook-no-charity-and-free-free-basics-comes-price37571

Sarikakis, K. (2004). Ideology and policy: Notes on the shaping of the Internet. First Monday, Vol 9 (8). Retrieved from http://firstmonday.org/ojs/index.php/fm/article/view/1167/1087\#s6

Save the Internet (2016, January 7). Joint submission from Indian start-ups for consultation paper on differential pricing. Retrieved from

http://www.trai.gov.in/WriteReadData/ConsultationPaper/Document/20160115042507882715 8Savetheinternet_in_Coalition.pdf

Sharma, A. (2008). Paradoxes of Empowerment: Development, Gender and Governance in Neoliberal India. New Delhi: Zubaan.

Sharma, A. (2016). Counter-comments to the TRAI Consultation on Differential Pricing. Retrieved from

http://www.trai.gov.in/WriteReadData/ConsultationPaper/Document/20160115035139117090 4Anushka_Sharma.pdf

Singh, P. (2016). Free Basics, now through the backdoor. The Hindu. Retrieved from http://www.thehindu.com/opinion/op-ed/parminder-jeet-singh-india-and-facebook-free-basic s-now-through-the-backdoor/article8807948.ece

Sony Pictures. (2016, January 13). Counter-comments to the TRAI Consultation on Differential Pricing. Retrieved from

http://www.trai.gov.in/WriteReadData/ConsultationPaper/Document/20160115034143382716 
2Sony_Pictures_Networks_India_Pvt_Ltd.pdf

Svennson, P. (2009). Verizon, Google in Android Partnership. Retrieved from

http://www.nbcnews.com/id/33192558/ns/technology_and_science-tech_and_gadgets/t/veri zon-google-android-partnership/\#.V4kNkO2fGPQ

TRAI. (2016a). Comments received from the stakeholders towards the Consultation Paper on differential pricing for data services. Retrieved from

http://www.trai.gov.in/WriteReadData/ConsultationPaper/Document/2016010909225273720 65Comments_data_services.pdf

TRAI. (2016b). Prohibition of discriminatory tariffs for data services regulations, 2016.

Retrieved from

http://www.trai.gov.in/WriteReadData/WhatsNew/Documents/Regulation_Data_Service.pdf

TRAI. (2016c). Letter to Facebook. Retrieved from

http://trai.gov.in/WriteReadData/Miscelleneus/Document/201601190319214139629TRAI_lett er_to_FB_dated_18_01_2016.pdf

TRAI. (2016d). Consultation Paper on Free Data. May 2016. Retrieved from http://www.trai.gov.in/WriteReadData/ConsultationPaper/Document/CP_07_free_data_cons ultation.pdf

Wikileaks. (n.d.) Sony. Retrieved from https://wikileaks.org/sony/emails/emailid/107641

Winokur, M. 2008.The Ambiguous Panopticon: Foucault and the Codes of Cyberspace. In Kroker, A. and Kroker, M. Critical Digital Studies: A Reader. University of Toronto Press Incorporated: London.

World Bank. (2016). World Development Report 2016: Digital Dividends. Retrieved from http://www-wds.worldbank.org/external/default/WDSContentServer/WDSP/IB/2016/01/13/o 90224bo8405ea05/2_o/Rendered/PDF/Worldodevelopmoooodigitalodividends.pdf

Yoo, C. (2016, January 14). Counter-comments to the TRAI Consultation on Differential Pricing. Retrieved from

http://www.trai.gov.in/WriteReadData/ConsultationPaper/Document/20160115040354335931 1Christopher_S_Yoo.pdf

\section{FOOTNOTES}

1. For more on the P2P Foundation: https://p2pfoundation.net/

2. The Free Basics service was previously called Internet.org

3. According to the Alliance for Affordable Internet, zero-rating refers to "services that make certain content or applications available at no additional cost to the customer".

4. Concepts over which there is "unity at the level of notions and ideals (but are) enacted through a multiplicity of 'instantiations' or realisations" (Gallie, 1956 as cited in McGee and Edwards, 2016).

5. Submissions received between December 2015 to January 2016, in response to TRAI's second consultation paper on differential pricing for data services issued on 9 December 2015. 
6. One counter-comment was submitted by IT for Change, the NGO that the authors work with.

7. Opponents are Save the Internet campaign, the media company Sony Pictures, two civil society coalitions, five civil society organisations, a software-industry think-tank, a film industry professional body, a tech entrepreneur, a member of parliament, an academic and two concerned individuals.

8. Proponents are Facebook, three TSP/ISP associations, a professional technologist think-tank, a civil society organisation, and an academic.

9. 'Internet for all' campaign

10. The platform was not available anymore, at the time of writing. 